\title{
Using the TxtAB Operon to Quantify Pathogenic Streptomyces in Potato Tubers and Soil
}

\author{
Xinshun Qu, Leslie A. Wanner, and Barbara J. Christ
}

First and third authors: Department of Plant Pathology, The Pennsylvania State University, University Park 16802; and second author: U.S. Department of Agriculture-Agricultural Research Services Genetic Improvement of Fruit and Vegetable Laboratory, 10300 Baltimore Ave., Beltsville, MD 20705.

Accepted for publication 10 November 2007.

\begin{abstract}
Qu, X., Wanner, L. A., and Christ, B. J. 2008. Using the $t x t A B$ operon to quantify pathogenic Streptomyces in potato tubers and soil. Phytopathology 98:405-412.

The phytotoxin thaxtomin, produced by plant pathogenic Streptomyces species, is the only known pathogenicity determinant for common scab diseases of potato and other root and tuber crops. Genes encoding thaxtomin synthetase $(t x t A B)$ are found on a pathogenicity island characteristic of genetically diverse plant pathogenic Streptomyces species. In this study, an SYBR Green quantitative real-time polymerase chain reaction (PCR) assay using primers designed to anneal to the $t x t A B$ operon of Streptomyces was developed to quantify pathogenic bacterial populations in potatoes and soil. The real-time PCR assay was specific for pathogenic Streptomyces strains. The detection limit of the assay was $10 \mathrm{fg}$ of the

target DNA, or one genome equivalent. Cycle threshold $(\mathrm{Ct})$ values were linearly correlated with the concentration of the target DNA (correlation coefficient $R^{2}=0.99$ ) and were not affected by the presence of plant DNA extracts, indicating the usefulness of the assay for quantitative analyses of the pathogenic bacteria in plant tissues. The amount of pathogenic Streptomyces DNA in total DNA extracts from $1 \mathrm{~g}$ asymptomatic and symptomatic tubers was quantified using the assay and ranged from $10^{1}$ to $10^{6} \mathrm{pg}$. A standard curve was established to quantify pathogenic Streptomyces in soil. Using the standard curve, numbers of pathogenic Streptomyces colony forming units were extrapolated to range from $10^{3}$ to $10^{6}$ per gram of soil from potato fields where common scab was found. This real-time PCR assay using primers designed from the $t x t A B$ operon allows rapid, accurate, and cost effective quantification of pathogenic Streptomyces strains in potato tubers and in soil.
\end{abstract}

Streptomyces is the most widely studied and well known genus of Actinobacteria, a group of gram-positive filamentous bacteria that are predominantly soil saprophytes. Of the more than 400 Streptomyces species described, only a few are known to be pathogenic and these species infect the underground portions of a range of host plants including potato, carrot, radish, beet, and other tap root crops $(11,26)$. Scab lesions on the surfaces of root and tuber vegetables caused by pathogenic Streptomyces species reduce vegetable quality and marketability, resulting in significant economic loss (14). Among the plant diseases caused by Streptomyces, potato common scab is the most economically important $(22,26)$.

Streptomyces is both seed- and soilborne. Streptomycetes can survive for many years in soil in the absence of potatoes due to their ability to live saprophytically and infect other plants (21). The bacteria also can be spread on infected seed tubers $(32,37)$ and tubers harboring low levels of pathogenic Streptomyces, and without visible symptoms, can transmit common scab to their progeny (32). There have been reports that the inoculum density of pathogenic Streptomyces on tuber surfaces and in soil was positively related to scab disease severity and incidence $(17,18$, 33). Plate counting methods have been used to estimate quantities of pathogenic Streptomyces in soil and on tubers $(6,17,18,31,32)$, but they lack specificity and are too tedious to accommodate large numbers of samples. To relate pathogen quantities to disease outcome in field situations, a fast, cheap, specific and sensitive

Corresponding author: B. J. Christ; E-mail address: ebf@psu.edu

doi:10.1094/PHYTO-98-4-0405

This article is in the public domain and not copyrightable. It may be freely reprinted with customary crediting of the source. The American Phytopathological Society, 2008. method is needed that can accurately quantify the pathogenic bacteria on tubers and in soil and can accommodate large sample numbers. Ideally, the method would identify all pathogenic strains of the several common scab-causing Streptomyces species.

Conventional polymerase chain reaction (PCR) assays using primers targeted to variable regions in 16S rRNA genes have been developed for species-specific detection of pathogenic Streptomyces on scabby tubers $(24,34)$. However, species identification may give no indication of its pathogenicity, since both pathogenic and nonpathogenic strains have been classified within the same species (34). Molecular analyses, including 16S rDNA sequence comparisons $(20,30)$, fatty acid methyl ester profiles (28), restriction fragment length polymorphisms (8), and DNA-DNA hybridization (12), have been carried out to identify markers specific for pathogenicity, but results showed genetic diversity among pathogenic strains.

Recently, pathogenicity genes, including genes for the bio-

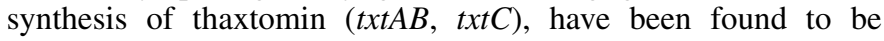
clustered in a large chromosomal region that functions as a pathogenicity island (PAI) in Streptomyces $(19,27)$. Thaxtomin plays a critical role in the pathogenicity of scab-producing strains and is a pathogenicity determinant on potato tubers $(10,13,23,25)$. A $100 \%$ correlation between pathogenicity and the production of thaxtomin on oatmeal agar or the presence of thaxtomin biosynthetic $t x t A B$ genes has been reported (3,27,32-34). A second gene, $n e c 1$, is conserved among most scab-causing Streptomyces species and is associated with a necrogenic phenotype on potato tubers $(3-5,16)$. While a good correlation between the presence of the necl gene and pathogenicity has been reported, some nonpathogenic necl-positive strains (31) and numerous pathogenic neclnegative strains $(2,3,20,33-35)$ have been described. Therefore, the $\operatorname{txt} A B$ operon was chosen as a marker for pathogenic Streptomyces. 
Since real-time PCR can be applied to quantify pathogenic Streptomyces and the $t x t A B$ operon is the best marker for pathogenic strains, the aims of the present study were to (i) develop a quantitative real-time PCR assay specific for pathogenic Streptomyces strains using the $t x t A B$ operon as the target gene, (ii) use the assay to quantify pathogenic Streptomyces strains in potato tubers, and (iii) use the assay to quantify pathogenic Streptomyces strains in naturally infested field soils.

\section{MATERIALS AND METHODS}

Streptomyces strains. The Streptomyces strains analyzed in this study are listed in Table 1. Type strains of ATCC 49173 (S. scabies, syn. S. scabiei), ATCC 33282 (S. europaeiscabiei), ATCC 700248 (S. turgidiscabies), ATCC 700526 (S. aureofaciens), and ATCC 49003 (S. acidiscabies) were obtained from American Type Culture Collection (ATCC, Manassas, VA). The other Streptomyces strains and species were isolated from scab lesions on potato tubers according to the method of Wanner (33), and tested for pathogenicity on radishes and/or potatoes (33,35; L. A. Wanner, unpublished data). Species determinations were made by cloning and sequencing the $16 \mathrm{~S}$ ribosomal RNA gene and comparing the rrn sequences obtained to sequences deposited in GenBank (34; D. K. Lakshman and L. A. Wanner, unpublished data).

Potato tuber samples. Twenty-four symptomatic (common scab or powdery scab lesions) and asymptomatic potato tuber samples were used in this study (Table 2). Tubers from Pennsylvania were collected from research plots at the Russell Larson Agriculture Research Center at Rock Springs, used in disease resistance screening. The tubers from other states were sent by potato growers or researchers for identification of scab diseases. Pathogen-free mini-tubers cv. Russet Burbank (Summit Plant Laboratories, Inc., Fort Collins, CO) were used as negative controls. Tubers were washed gently under running tap water to remove soil particles from the surface. For symptomatic tubers, $1 \mathrm{~g}$ of scab lesion tissue was used for DNA extraction. For asymptomatic tubers, $1 \mathrm{~g}$ of peel tissue was used for DNA extraction.
Soil samples. Thirty-eight soil samples were collected from potato fields in six states where common scab is found (Table 3 ). In Pennsylvania, eight soil samples were randomly collected from one field. In other states, one sample was collected for each field. Two soil samples were collected from a field with powdery scab but no common scab history in Alamosa, Colorado, and used as negative controls (Table 3). Potato varieties, susceptibility, and incidence of common scab disease were recorded (Table 3). The disease incidence was calculated as a percentage of common scab tubers out of the total number of tubers sampled from the field. Soil samples $(500 \mathrm{~g})$ were collected at harvest. Samples were well-mixed before triplicate $1-\mathrm{g}$ aliquots were taken for DNA extraction. Streptomyces-spiked soils were prepared and used to determine PCR sensitivity and to generate a standard curve for PCR quantification. Bacterial spores were harvested using a sterile glass rod to gently scrape 2- to 3-week old Streptomyces cultures on yeast-malt extract (YME) agar plates (29) flooded with $5 \mathrm{ml}$ of sterile water. Spore numbers were determined by counting on a hemacytometer slide, and the number of colony forming units (CFU) verified by agar plate counts. Playground sand (purchased from Home Depot) was mixed 1:1 (vol/vol) with ProMix Plus. The soil mixture was sterilized by autoclaving 6 liter volumes three times, with 2 to 3 days between autoclavings. Autoclaved sand/soil was spiked with $10^{1}, 10^{2}, 10^{3}, 10^{4}$, $10^{5}, 10^{6}, 10^{7}, 10^{8}$, and $10^{9} \mathrm{CFU}$ of pathogenic Streptomyces strain ME01-11h per gram by adding a dilution series of bacterial spores in a volume of $100 \mu \mathrm{l}$ to $1 \mathrm{~g}$ of sterile soil. Triplicate samples were prepared for each spore dilution and used for DNA extractions.

DNA extraction. Streptomyces strains were grown at $28^{\circ} \mathrm{C}$ for 3 days in YME, and cells were pelleted to obtain approximately $100-\mathrm{mg}$ aliquots that were stored at $-20^{\circ} \mathrm{C}$ until use. DNA was isolated from frozen cells using a Bio101 FAST DNA kit (QBiogene, now MP Biomedicals, Solon, OH). DNA was extracted from potato tuber tissue using the CTAB (hexadecylmethylammonium bromide) method (9). Soil DNA was extracted using a Bio101 Soil DNA kit (Q-Biogene, now MP Biomedicals) and a FAST-prep machine according to manufacturer protocols, with

TABLE 1. Description of Streptomyces strains used in this study

\begin{tabular}{|c|c|c|c|c|c|}
\hline Strain ${ }^{\mathrm{a}}$ & $\begin{array}{l}\text { Closest genus and species }{ }^{b} \\
\text { (GenBank accession number) }\end{array}$ & Origin & Pathogenicity ${ }^{\mathrm{c}}$ & $T x t A B^{\mathrm{d}}$ & $\mathrm{Necl}^{\mathrm{e}}$ \\
\hline ME01-11h & S. scabies & Typical common scab lesion on potato tuber, Presque Isle, ME & + & + & + \\
\hline ME02-6991.2B & S. glauciniger & lesion atypical for common scab, potato tuber; Presque Isle, ME & - & - & - \\
\hline ME02-6985.2A & Ochrobactrum anthropii & Netted surface potato tuber; Presque Isle, ME & - & - & - \\
\hline ME03-5709D & S. coelescens (EU080957) & Typical common scab lesion on potato tuber, Presque Isle, ME & - & - & - \\
\hline ND04-1A & S. clavifer; $S$. griseus & Typical common scab lesion on potato tuberWilliston, ND & - & - & - \\
\hline WI03-5B & S. griseus; S. setoni $(\mathrm{EU} 080963)$ & Typical common scab lesion on potato tuber, Hancock, WI & - & - & - \\
\hline ID01-15B & S. badius; $S$. sindensis (EU080940) & Typical common scab lesion on potato tuber, American Falls, ID & - & - & - \\
\hline NY02-3A & S. stelliscabiei (DQ861640) & Typical common scab lesion on potato tuber, Ithaca, NY & + & + & + \\
\hline ID01-12c & Streptomyces sp. IdX (DQ341443) & Typical common scab lesion on potato tuber, location not noted, ID & + & + & - \\
\hline $\mathrm{OH} 01-5 \mathrm{D}$ & S. scabies (DQ861637) & Typical common scab lesion on potato tuber, Urbana, $\mathrm{OH}$ & + & + & + \\
\hline ATCC 49173 & S. scabies (type strain) (gi971124) & Potato tuber New York & + & + & + \\
\hline ID01-16c & S. europaeiscabiei (DQ861638) & Typical common scab lesion on potato tuber; American Falls, ID & + & + & + \\
\hline ATCC 33282 & $\begin{array}{l}\text { S. scabiei }(\text { S. europaeiscabiei REF) } \\
\quad \text { (gi5263068) }\end{array}$ & Soil & + & + & + \\
\hline ATCC 700248 & $\begin{array}{l}\text { S. turgidiscabies (type strain) } \\
\quad \text { (AB026221) }\end{array}$ & Potato tuber, Hokkaido, Japan, 1993 & + & + & + \\
\hline ATCC 700526 & $\begin{array}{l}\text { S. aureofaciens (type strain) } \\
\text { (gi3550677) }\end{array}$ & Scab lesion on potato tuber, Loimaa, Finland, 1995 & - & - & - \\
\hline ATCC 49003 & $\begin{array}{l}\text { S. acidiscabies (type strain) } \\
\text { (AB026220) }\end{array}$ & Potato tuber, ME & + & + & + \\
\hline
\end{tabular}

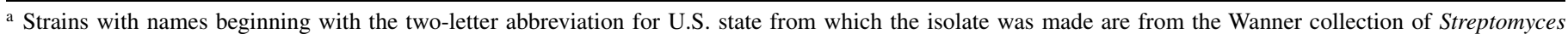
isolates at USDA-ARS in Beltsville, MD; the digits following letters indicate the year of isolation and a unique identifier. ATCC strains came from the American Type Culture Collection in Manassas, VA.

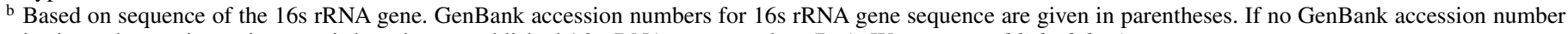
is given, the species assignment is based on unpublished $16 \mathrm{~s}$ rDNA sequence data (L. A. Wanner, unpublished data).

c Pathogenicity tested on radishes and/or potatoes $(33,35)$.

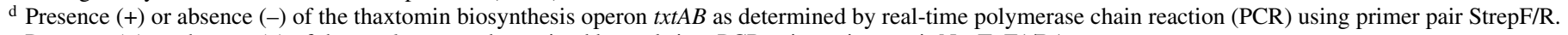

e Presence (+) or absence (-) of the necl gene as determined by real-time PCR using primer pair NecTqF1/R1. 
the minor modification of an additional ethanol:salt wash before eluting the DNA in $200 \mu \mathrm{l}$ of TE buffer or sterile distilled water.

Primer design and SYBR Green real-time PCR amplification. Sequences deposited in GenBank for the $t x t A B$ gene from S. acidiscabies (AF255732) and from S. turgidiscabies (AY707081) were aligned using the Clustal $\mathrm{W}$ alignment tool in DNAStar software (DNAStar Inc., Madison, WI). A real-time PCR forward primer, StrepF, and a reverse primer, StrepR (Table 4), were designed from a region of $100 \%$ similarity using Primer Express version 2.0 software (Applied Biosystems, Foster City, CA). The specificity of the primer pair was checked by comparing the NCBI nonredundant nucleotide sequence database for similarity to other organisms using BLASTn, and by real-time PCR amplifications of DNA from potato tissues and potato pathogens Alternaria solani, Colletotrichum coccodes, Fusarium sambucinum, Helminthosporium solani, Spongospora subterranea, and Phytophthora infestans. A real-time PCR primer pair NecTqF1/R1 (Table 4) designed from the necl gene region by Cullen and Lees (7) was used in this study to examine the relationship between the presence of necl gene and pathogenicity. A third real-time PCR primer pair $\mathrm{CoxF} / \mathrm{R}$ (Table 4) designed to amplify the potato cytochrome oxidase gene by Weller et al. (36) was used as a control to detect potato DNA in Streptomyces-negative samples.

The primer pair StrepF/R was initially tested in an SYBR Green real-time PCR assay. The parameters tested included the concentrations of $\mathrm{MgCl}_{2}$ (2.5 to $\left.5 \mathrm{mM}\right)$, StrepF/R primers $(0.2$ to $1 \mu \mathrm{M})$, and DNA templates. Based on the results of these tests, optimized real-time PCR amplifications were performed in $25-\mu \mathrm{l}$ reaction mixtures containing 1× QuantiTect SYBR Green PCR Master Mix (QIAGEN, Valencia, CA) and $0.3 \mu \mathrm{M}$ of each primer. Ten nanograms of Streptomyces DNA, or $0.5 \mu \mathrm{l}$ of tuber DNA extract, or $10 \mu \mathrm{l}$ of soil DNA extract was used as DNA template per reaction. Real-time PCR amplifications were carried out on a Smart Cycler (Cepheid, Sunnyvale, CA) with an initial activation step at $95^{\circ} \mathrm{C}$ for $15 \mathrm{~min}$, followed by 45 cycles of $95^{\circ} \mathrm{C}$ for $15 \mathrm{~s}$, $60^{\circ} \mathrm{C}$ for $30 \mathrm{~s}$, and $72^{\circ} \mathrm{C}$ for $30 \mathrm{~s}$. Melting curve analysis was performed for each reaction to check the presence of primer dimers or nonspecific products. In the initial tests, the PCR products were separated by electrophoresis on $1.5 \%$ agarose gels to verify the size of the amplified products and to check for the presence of primer dimers or nonspecific bands.

The sensitivity limit and quantification range of the SYBR Green real-time PCR assay was evaluated by using serial dilution of genomic DNA ranging from $10 \mathrm{ng}$ to $1 \mathrm{fg}$ from pathogenic Streptomyces strain OH01-5D. A standard curve was constructed by plotting $\mathrm{Ct}$ values versus the log of the initial concentration of Streptomyces DNA. To determine whether the presence of plant DNA and co-extracted compounds affect the amplification of target bacterial DNA, the SYBR Green real-time PCR assay was performed using the serial dilution of pathogenic Streptomyces DNA plus $1 \mu \mathrm{l}$ of DNA extract from mini-tuber tissues per reaction.

To test whether the DNA extracts from field soil samples were PCR-inhibitor-free, $10 \mathrm{ng}$ of potato DNA from mini-tuber was added to the reaction mix containing $10 \mu \mathrm{l}$ of field soil DNA extracts and amplified by real-time PCR using potato primer pair CoxF/R. As a control, $10 \mu \mathrm{l}$ of sterilized distilled water was used to replace the same volume of DNA extracts from soil, with only $10 \mathrm{ng}$ of potato DNA in the reaction mix. Cox $\mathrm{Ct}$ values were obtained from each soil sample and the control. $\Delta \mathrm{Ct}$ was calculated as follows: $\Delta \mathrm{Ct}=(\mathrm{Ct}$ of Cox in sample tested $)-(\mathrm{Ct}$ of Cox in control).

Sequencing of real-time PCR products. To ensure that the real-time PCR products were amplified from pathogenic Streptomyces DNA, the PCR products of four samples, two tuber samples, T1 and T12 (Table 2), and two soil samples, PA1 and ID1 (Table 3), were sequenced. Following real-time PCR, the products were separated on a $1 \%$ low-melting agarose gel, purified with the QIAquick PCR Gel Purification Kit (QIAGEN, Valencia, CA), and sequenced using primers StrepF and StrepR with the ABI automated sequencer at the Nucleic Acid Facility, Pennsylvania State University.

TABLE 2. The results of real-time polymerase chain reaction (PCR) quantification of pathogenic Streptomyces on potato tuber samples

\begin{tabular}{|c|c|c|c|c|c|}
\hline Sample & Symptom & Variety & Origin & $\mathrm{Ct}$ value $^{\mathrm{a}}$ & $\begin{array}{c}\text { Amount of pathogenic } \\
\text { Streptomyces DNA (pg) }\end{array}$ \\
\hline $\mathrm{T} 1$ & Common scab & Snowden & NY & $20.41 \pm 0.16$ & $6.49 \times 10^{6}$ \\
\hline $\mathrm{T} 2$ & Common scab & Snowden & NY & $21.54 \pm 0.03$ & $2.93 \times 10^{6}$ \\
\hline $\mathrm{T} 3$ & Common scab & Snowden & NY & $19.40 \pm 0.17$ & $9.60 \times 10^{6}$ \\
\hline $\mathrm{T} 4$ & Common scab & Unknown & $\mathrm{MN}$ & $24.12 \pm 0.48$ & $5.05 \times 10^{5}$ \\
\hline $\mathrm{T} 5$ & Common scab & Unknown & $\mathrm{MN}$ & $22.14 \pm 0.39$ & $1.98 \times 10^{6}$ \\
\hline T6 & Common scab & Unknown & $\mathrm{ME}$ & $21.38 \pm 0.30$ & $3.32 \times 10^{6}$ \\
\hline $\mathrm{T} 7$ & Common scab & Klondike Goldust & ID & $26.14 \pm 0.19$ & $1.19 \times 10^{5}$ \\
\hline $\mathrm{T} 8$ & Common scab & Shepody & PA & $26.06 \pm 0.23$ & $1.27 \times 10^{5}$ \\
\hline T9 & $\mathrm{Scab}^{\mathrm{c}}$ & Shepody & $\mathrm{PA}$ & $38.16 \pm 0.39$ & $2.81 \times 10^{1}$ \\
\hline $\mathrm{T} 10$ & Scab & Shepody & PA & $36.69 \pm 0.78$ & $8.33 \times 10^{1}$ \\
\hline $\mathrm{T} 11$ & Scab & Shepody & PA & $27.70 \pm 0.31$ & $4.06 \times 10^{4}$ \\
\hline $\mathrm{T} 12$ & Scab & Shepody & PA & $31.99 \pm 0.27$ & $2.04 \times 10^{3}$ \\
\hline $\mathrm{T} 13$ & Scab & Bake King & NY & $28.98 \pm 0.21$ & $1.66 \times 10^{4}$ \\
\hline $\mathrm{T} 14$ & Scab & Green Mountain & NY & $28.71 \pm 0.23$ & $2.00 \times 10^{4}$ \\
\hline $\mathrm{T} 15$ & Scab & Chippewa & NY & $26.04 \pm 0.36$ & $1.25 \times 10^{5}$ \\
\hline $\mathrm{T} 16$ & Asymptomatic & Dark Red Norland & PA & $39.49 \pm 1.76$ & $1.83 \times 10^{1}$ \\
\hline $\mathrm{T} 17$ & Asymptomatic & Dark Red Norland & PA & $39.62 \pm 1.61$ & $1.53 \times 10^{1}$ \\
\hline $\mathrm{T} 18$ & Asymptomatic & Dark Red Norland & PA & $38.66 \pm 0.62$ & $2.05 \times 10^{1}$ \\
\hline $\mathrm{T} 19$ & Asymptomatic & Dark Red Norland & $\mathrm{PA}$ & $\mathrm{ND}^{\mathrm{d}}$ & ND \\
\hline $\mathrm{T} 20$ & Asymptomatic & Dark Red Norland & $\mathrm{PA}$ & ND & ND \\
\hline $\mathrm{T} 21$ & Asymptomatic & Dark Red Norland & $\mathrm{PA}$ & ND & ND \\
\hline $\mathrm{T} 22$ & Powdery scab & Unknown & WY & ND & ND \\
\hline $\mathrm{T} 23$ & Powdery scab & Unknown & WY & ND & ND \\
\hline $\mathrm{T} 24$ & Asymptomatic & $\begin{array}{l}\text { Pathogen-free mini-tuber } \\
\text { cv. Russet Burbank }\end{array}$ & $\mathrm{CO}$ & ND & ND \\
\hline
\end{tabular}

a Data are means \pm standard deviation from three replicate quantitative real-time PCR amplifications.

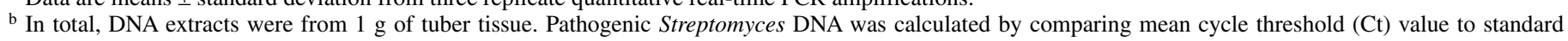
curve and then multiplying by dilution factor for each sample.

c The visible lesion was not a typical symptom of common scab; could be common scab or powdery scab.

d ND = pathogenic Streptomyces was not detected 


\section{RESULTS}

Specificity of the real-time PCR assay. The sequences of primers StrepF and StrepR were compared with sequences in GenBank using a BLAST search and no similarity to other organisms was found. An SYBR Green real-time PCR assay using primer pair StrepF/R was optimized with $10 \mathrm{ng}$ of DNA per reaction. The DNA was isolated from a pathogenic Streptomyces strain, OH01-5D. Under optimal conditions (described above), the primer pair amplified a predicted 71-bp fragment with a $\mathrm{Ct}$ value of 20.96, and no nonspecific products or primer dimers were generated after 45 cycles of amplification as confirmed by melting curve analyses and agarose gel observations (data not shown). No fluorescence was detected in real-time PCR using DNA from potato tissues or from common potato tuber pathogens Alternaria solani, Colletotrichum coccodes, Fusarium sambucinum, Helminthosporium solani, Spongospora subterranean, and Phytophthora infestans (data not shown). The capacity of the PCR assay to discriminate between pathogenic and nonpathogenic strains was tested against DNA from nine known pathogenic Streptomyces strains representing seven species and from seven nonpathogenic species. Fluorescence signal was detected for each of the nine pathogenic strains and no signal was detected for any nonpathogenic species (Table 1). The sequences of real-time PCR products from two tuber samples $\mathrm{T} 1$ and $\mathrm{T} 12$ and two soil samples PA1 and ID1 were identical to the sequences of the pathogenic Streptomyces txt $A B$ gene. These results showed that the PCR assay was specific for pathogenic Streptomyces species.

For comparison, a primer pair NecTqF1/R1 designed from necl gene was also used in the SYBR Green real-time PCR assay against DNA from the nine pathogenic Streptomyces strains and seven nonpathogenic species. No fluorescence signal was generated from seven nonpathogenic Streptomyces species and one pathogenic strain (strain ID01-12C), while signal was detected for eight other pathogenic Streptomyces strains (Table 1).

Sensitivity and quantification range of the real-time PCR assay. The detection limit and quantification range of the SYBR Green real-time PCR assay using primer pair StrepF/R was determined by using serial dilution of pathogenic Streptomyces DNA. The real-time PCR amplification profiles are shown in Figure 1A. The reliable lower limit of detection was $10 \mathrm{fg}$ of genomic Streptomyces DNA. Ct values were variable for $1 \mathrm{fg}$ DNA and,

TABLE 3. The results of real-time polymerase chain reaction (PCR) quantification of pathogenic Streptomyces in potato field soil samples

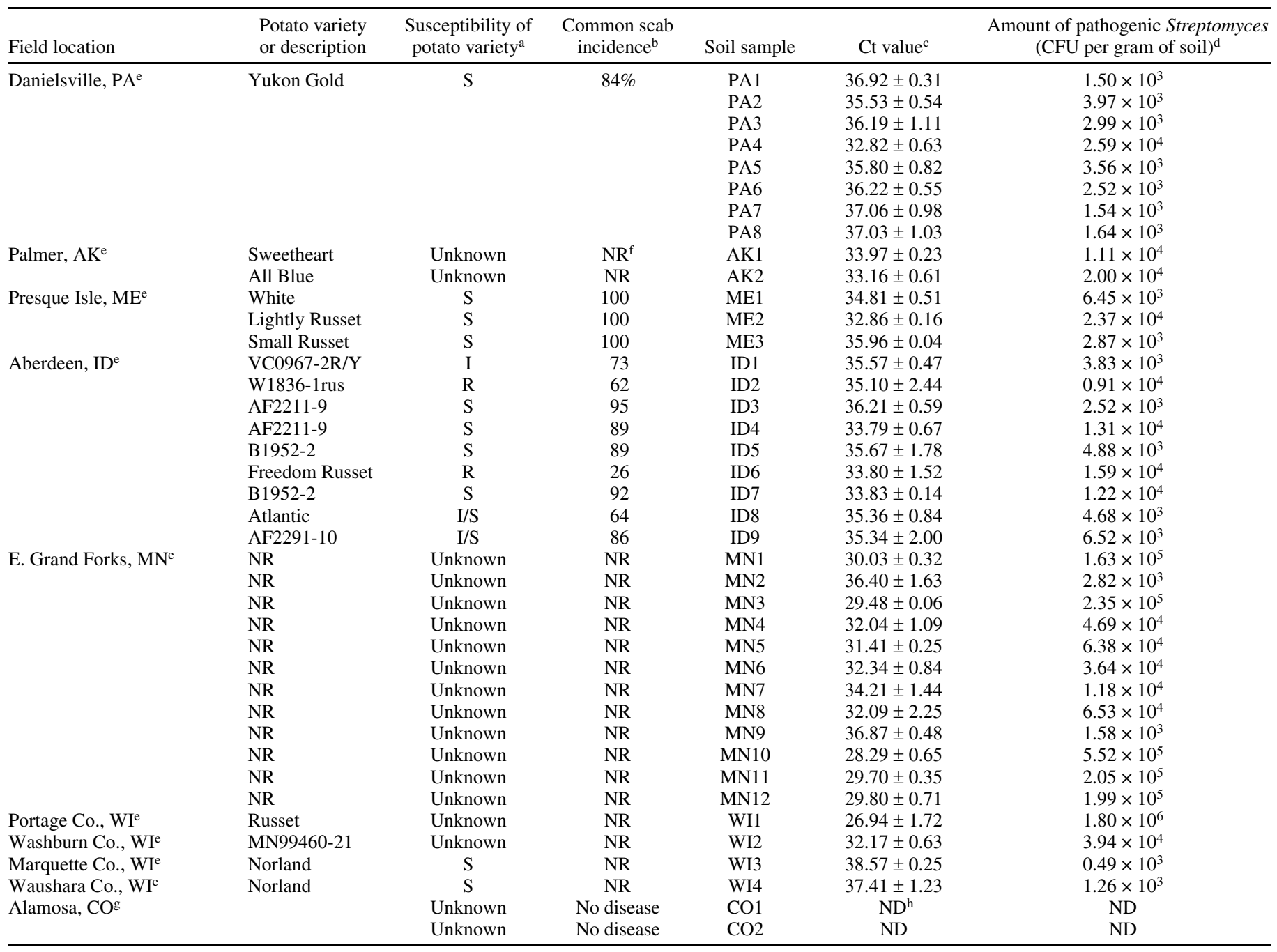

a $\mathrm{S}=$ susceptible; $\mathrm{I}=$ intermediate; $\mathrm{R}=$ resistant.

b The disease incidence was calculated as a percentage of scabby tubers out of total number of tubers from the field.

c Data are means \pm standard deviation from three replicate DNA extractions and quantitative real-time PCR amplifications.

d Calculated by comparing mean cycle threshold $(\mathrm{Ct})$ value to standard curve.

e Location with a history of common scab.

${ }^{f} \mathrm{NR}=$ not recorded.

g Location with a history of powdery scab but no common scab.

h ND = pathogenic Streptomyces was not detected. 
therefore, not included in the analysis. Based on a PCR assay of three replicate serial dilutions of Streptomyces DNA, a standard curve was constructed (Fig. 1B). The standard curve showed a linear response with a high correlation coefficient $\left(R^{2}=0.9946\right)$. The efficiency of the real-time PCR amplification was $100 \%$, determined using the formula, $\left(10^{[-1 / \text { slope }]}-1\right) \times 100$, indicating that the assay could be used for the accurate quantification of the bacterial DNA.

When $1 \mu$ of DNA extract from mini-tuber tissues was added to serial dilutions of Streptomyces DNA ranging from $10 \mathrm{ng}$ to $10 \mathrm{fg}$, results of real-time PCR assays based on three replicate experiments showed the mean $\mathrm{Ct}$ values for each dilution were similar to those obtained from serial dilution of Streptomyces DNA without added plant DNA extracts (data not shown), indicating that the real-time PCR can be used to quantify Streptomyces in infected plant tissues.

Quantification of pathogenic Streptomyces DNA in plant tissues. Twenty-four tuber samples were assessed by the SYBR green real-time PCR assay. Each tuber was evaluated three times by PCR and the amount of Streptomyces DNA was calculated by referring $\mathrm{Ct}$ values to the standard curve. The $\mathrm{Ct}$ values and the amount of Streptomyces DNA are shown in Table 2. Eight tubers with typical common scab symptoms were all positive for pathogenic Streptomyces, and $1.19 \times 10^{5}$ to $6.49 \times 10^{6} \mathrm{pg}$ of Streptomyces DNA was detected in total DNA extracts from $1 \mathrm{~g}$ of tuber lesion tissue. Seven scabby tubers which showed atypical common scab symptoms similar to powdery scab were also all positive for pathogenic Streptomyces, although 10- to 10,000-fold less Streptomyces DNA $\left(2.81 \times 10^{1}\right.$ to $\left.1.25 \times 10^{5} \mathrm{pg}\right)$ was detected in total DNA extracts from $1 \mathrm{~g}$ of tuber lesion tissue. Low levels of pathogenic Streptomyces were also detected in three out of six asymptomatic tubers: $1.53 \times 10^{1}$ to $2.05 \times 10^{1} \mathrm{pg}$ of Streptomyces DNA was detected in total DNA extracts from $1 \mathrm{~g}$ of tuber tissue. Pathogenic Streptomyces DNA was not detected in two typical powdery scab tubers or a pathogen-free mini-tuber.

For samples negative for pathogenic Streptomyces, a second SYBR Green real-time PCR assay using potato primer pair CoxF/R was performed to confirm whether the DNA extracts contained PCR inhibitors that would prevent PCR amplifications and result in false negatives. Fluorescence signal was detected in all of these samples (data not shown), indicating that these samples were truly Streptomyces negative, or the amount of Streptomyces DNA in the samples was below the detection limit, and that PCR inhibitors were not likely a problem.

Quantification of pathogenic Streptomyces in soils. To determine the detection limit and the relationship between the $\mathrm{Ct}$ values and the concentrations of pathogenic Streptomyces in soils, SYBR Green real-time PCR with the primer pair StrepF/R, was carried out using DNA extracts from ten Streptomyces-spiked soil samples containing from $10^{9}$ to $0 \mathrm{CFU}$ of pathogenic Streptomyces per gram of soil. The reliable detection limit in soil was $10^{3} \mathrm{CFU}$ per gram of soil. Streptomyces was not detected in samples containing 0 or $10^{1} \mathrm{CFU}$ per gram of soil. Ct values were variable for samples containing $10^{2} \mathrm{CFU}$. The data for the $10^{1}$ and $10^{2} \mathrm{CFU}$ levels were therefore omitted from the standard curve. The real-time PCR amplification profiles are shown in Figure 2A. A standard curve was calculated based on three replicate experiments (Fig. 2B). A linear regression was obtained with an $R^{2}$ value of 0.9931 . The efficiency of the real-time PCR amplification was $97 \%$, indicating that the assay could be used for the quantification of the bacteria in soil.

Thirty-eight soil samples which were collected from potato fields where common scab was found, were assessed by the realtime PCR assay. Pathogenic Streptomyces was detected in all of these samples. By comparing $\mathrm{Ct}$ values to the standard curve, the concentrations of pathogenic Streptomyces were calculated, and the mean concentration values from three experiments are shown in Table 3. Pathogenic Streptomyces were not detected in two soil samples collected from a field with powdery scab but no history of common scab (Table 3).

In tests to determine whether the DNA extracts from field soils contained PCR inhibitors, potato DNA was added to the field soil DNA extracts. In SYBR Green PCR assays, the Cox Ct value of the potato DNA control was 24.16 , and Cox $\mathrm{Ct}$ values of potato DNA added to DNA extracts from field soils ranged from 24.18 to 25.14 (Table 5). $\Delta \mathrm{Ct}$ ranged from 0.02 to 0.98 (Table 5), indicating that Cox was amplified at a similar efficiency between field soils and control and among field soils. These results demonstrated that field soil DNA extracts showed no PCR inhibition.

\section{DISCUSSION}

In this investigation we developed a quantitative real-time PCR assay specific to plant pathogenic Streptomyces. The SYBR Green
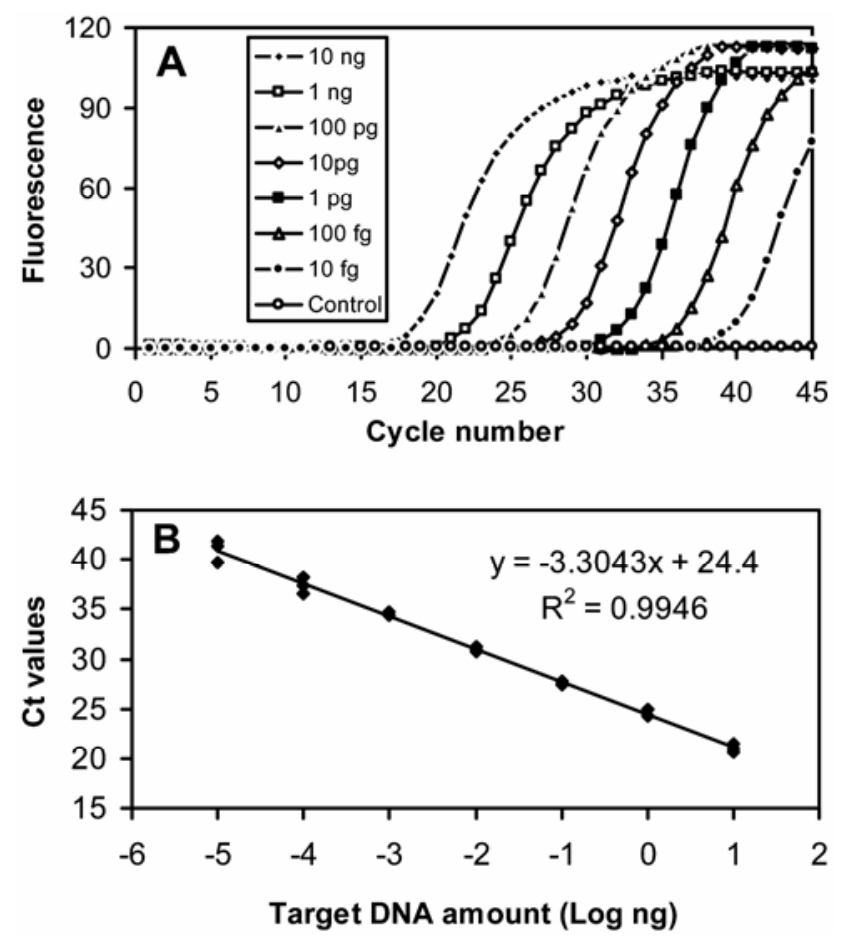

Fig. 1. A, Real-time polymerase chain reaction (PCR) amplification profile for a representative dilution series of DNA from pathogenic Streptomyces scabies strain OH01-5D. B, Standard curve obtained by plotting threshold cycle $(\mathrm{Ct})$ values against log serial dilutions of DNA (ng) from pathogenic Streptomyces strain OH01-5D. The standard curve is the result of three separate PCR analyses.

TABLE 4. Real-time polymerase chain reaction primers used in this study

\begin{tabular}{|c|c|c|c|c|c|}
\hline Target organism & Primer & Sequences $\left(5^{\prime}-3^{\prime}\right)$ & Target gene & Product size (bp) & Reference \\
\hline \multirow[t]{2}{*}{ Pathogenic Streptomyces } & StrepF & GCAGGACGCTCACCAGGTAGT & \multirow[t]{2}{*}{$\operatorname{txt} A B$} & \multirow[t]{2}{*}{71} & \multirow[t]{2}{*}{ This work } \\
\hline & StrepR & ACTTCGACACCGTTGTCCTCAA & & & \\
\hline \multirow[t]{2}{*}{ Pathogenic Streptomyces } & NecTqF1 & TCGCACTCTTGGAGATCTCATG & \multirow[t]{2}{*}{ necl } & \multirow[t]{2}{*}{83} & \multirow[t]{2}{*}{ Cullen and Lees (7) } \\
\hline & NecTqR1 & TCGTAAGAACGCGACGCTTT & & & \\
\hline \multirow[t]{2}{*}{ Potato } & CoxF & CGTCGCATTCCAGATTATCCA & \multirow[t]{2}{*}{$\operatorname{cox}$} & \multirow[t]{2}{*}{79} & \multirow[t]{2}{*}{ Weller et al. (36) } \\
\hline & CoxR & CAACTACGGATATATAAGAGCCAAAACTG & & & \\
\hline
\end{tabular}


assay developed uses primer pair StrepF/R designed to the sequence of the Streptomyces txtAB operon, which encodes a nonribosomal peptide synthetase that is found in all pathogenic Streptomyces $(13,19,27,33,34)$. When tested against DNA from 16 Streptomyces strains, potato tissues, and selected other soilborne potato pathogens, fluorescent signal was detected from nine strains previously determined to be pathogenic that represent all species of plant-pathogenic Streptomyces so far reported to occur in Europe and North America $(2,5,20,34,35)$. No fluorescent signal was obtained from seven nonpathogenic Streptomyces strains, from other common potato tuber pathogens, or from tissue-culture disease-free tubers, and no primer dimer was observed.

We obtained a detection limit of $10 \mathrm{fg}$ of Streptomyces DNA, corresponding to approximately 1 bacterial cell according to the genome size of a Streptomyces species (1). Considering that $t x t A B$ is a single copy gene, this assay is highly sensitive. Using primers developed on multi-copy genes such as $16 \mathrm{~S}$ rRNA may improve sensitivity, but it is difficult to design primers specific for all pathogenic strains because of the genetic similarity of 16S rRNA gene sequences in pathogenic and nonpathogenic Streptomyces strains, and because both pathogenic and nonpathogenic strains are found within a single species. Furthermore, quantification using single copy genes is not affected by variable numbers of tandem repeats found in multi-copy genes, and there is a potential to directly correlate $\mathrm{Ct}$ values with the pathogen biomass and/or with the number of propagules. Using serial dilutions of target DNA, high PCR amplification efficiency and high correlation coefficients between the amount of DNA and cycle thresholds were achieved. In addition, $\mathrm{Ct}$ values and correlation coefficients were not affected by the presence of plant extracts. These results demonstrate that the assay is appropriate for both qualitative and quantitative analyses of pathogen biomass in infected plant tissues.

For the PCR detection and quantification of pathogenic Streptomyces in soil, it is essential to have a method that extracts DNA free from PCR inhibitors. With DNA extracted using a Bio101 Soil DNA kit, we obtained a real-time PCR amplification efficiency of $97 \%$, even when $10 \mu \mathrm{l}$ of DNA extract (or $40 \%$ of
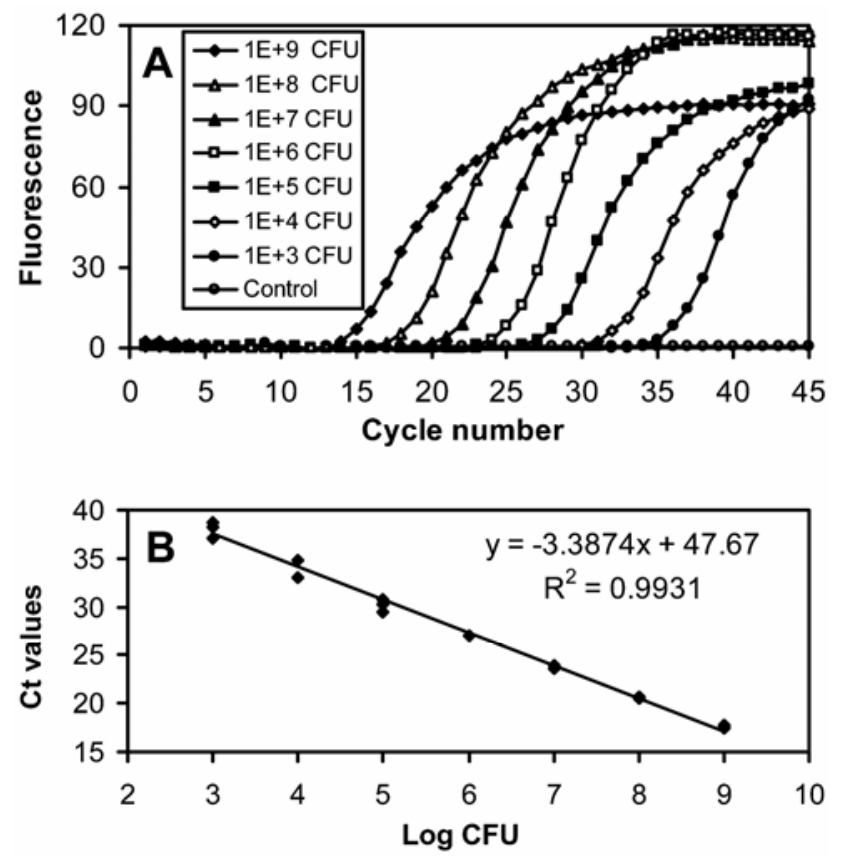

Fig. 2. A, Real-time polymerase chain reaction (PCR) amplification profile for DNA from soil spiked with $10^{3}, 10^{4}, 10^{5}, 10^{6}, 10^{7}, 10^{8}$, and $10^{9}$ colony forming units (CFU) of pathogenic Streptomyces per gram. B, Standard curve obtained by plotting threshold cycle $(\mathrm{Ct})$ values against the log of the numbers of pathogenic Streptomyces CFU in spiked soil. The standard curve is the result of three separate PCR analyses. the PCR volume) was used for amplification. No PCR inhibition was seen in field soil DNA extracts using a Cox real-time PCR assay, demonstrating that the DNA extraction method used adequately removes PCR inhibitors commonly co-extracted with DNA from soil. We conclude the assay is reliable, specific, and sensitive for the detection and quantification of pathogenic Streptomyces strains on tubers or in soil.

The assay was used to quantify the amount of pathogen in potato tuber and field soil samples. Approximately $10^{5}$ to $10^{6} \mathrm{pg}$ of DNA of pathogenic Streptomyces, corresponding to approximately $10^{7}$ to $10^{8}$ bacterial cells, was detected in total DNA extracts from $1 \mathrm{~g}$ of infected tubers with typical common scab symptoms. These numbers are similar to those of Wang and Lazarovits (31), who estimated 2 to $3 \times 10^{8} \mathrm{CFU} / \mathrm{g}$ of scabby tuber tissue. Populations in lesions from growers' potato storage after winter were estimated to range from $2 \times 10^{5}$ to $2 \times 10^{8} \mathrm{CFU} / \mathrm{g}$ of lesion tissue (31).

Actinobacteria have recently been estimated to make up an average of $13 \%$ of all soil bacteria, about a quarter of which can

TABLE 5. Real-time polymerase chain reaction (PCR) assays to test for PCR inhibitors in DNA extracts from field soil samples ${ }^{\mathrm{a}}$

\begin{tabular}{|c|c|c|}
\hline Soil sample & Cox $\mathrm{Ct}$ value & $\Delta \mathrm{Ct}^{\mathrm{b}}$ \\
\hline PA1 & 24.28 & 0.12 \\
\hline PA2 & 24.31 & 0.15 \\
\hline PA3 & 24.84 & 0.68 \\
\hline PA4 & 24.86 & 0.70 \\
\hline PA5 & 24.62 & 0.46 \\
\hline PA6 & 24.18 & 0.02 \\
\hline PA7 & 24.70 & 0.54 \\
\hline PA8 & 24.23 & 0.07 \\
\hline AK1 & 24.42 & 0.26 \\
\hline AK2 & 24.51 & 0.35 \\
\hline ME1 & 24.80 & 0.64 \\
\hline ME2 & 24.70 & 0.54 \\
\hline ME3 & 25.12 & 0.96 \\
\hline ID1 & 24.95 & 0.79 \\
\hline ID2 & 24.36 & 0.20 \\
\hline ID3 & 24.48 & 0.32 \\
\hline ID4 & 24.23 & 0.07 \\
\hline ID5 & 24.83 & 0.67 \\
\hline ID6 & 24.39 & 0.23 \\
\hline ID7 & 24.33 & 0.17 \\
\hline ID8 & 24.83 & 0.67 \\
\hline ID9 & 24.18 & 0.02 \\
\hline MN1 & 24.39 & 0.23 \\
\hline MN2 & 24.79 & 0.63 \\
\hline MN3 & 24.35 & 0.19 \\
\hline MN4 & 24.65 & 0.49 \\
\hline MN5 & 24.99 & 0.83 \\
\hline MN6 & 24.84 & 0.68 \\
\hline MN7 & 25.12 & 0.96 \\
\hline MN8 & 24.72 & 0.56 \\
\hline MN9 & 24.64 & 0.48 \\
\hline MN10 & 25.14 & 0.98 \\
\hline MN11 & 25.14 & 0.98 \\
\hline MN12 & 24.77 & 0.61 \\
\hline WI1 & 24.91 & 0.75 \\
\hline WI2 & 24.93 & 0.77 \\
\hline WI3 & 24.30 & 0.14 \\
\hline WI4 & 24.86 & 0.70 \\
\hline $\mathrm{CO} 1$ & 24.97 & 0.81 \\
\hline $\mathrm{CO} 2$ & 24.58 & 0.42 \\
\hline Control $^{\mathrm{c}}$ & 24.16 & \\
\hline
\end{tabular}

a Ten microliters of DNA extracts from each soil sample plus $10 \mathrm{ng}$ of potato DNA from mini-tuber was used for real-time PCR amplification using potato primer pair $\mathrm{CoxF} / \mathrm{R}$.

b $\Delta \mathrm{Ct}=(\mathrm{Ct}$ of Cox in sample tested $)-(\mathrm{Ct}$ of Cox in control). $\Delta \mathrm{Ct}$ ranged from 0.02 to 0.98 , indicating that $C o x$ was amplified at a similar efficiency between field soils and control and among field soils.

${ }^{c}$ Ten microliters of sterilized distilled water was used to replace the same volume of DNA extracts from soil, with only $10 \mathrm{ng}$ of potato DNA in the reaction mix. 
confidently be assigned to one of 148 described genera including Streptomyces (15). This means that soils could contain, on average, $3 \times 10^{7}$ streptomycetes per gram. Estimates of the percentage of soil streptomycetes that are plant pathogens range from less than 3 to $9 \%(6,17)$, with higher proportions being found in the rhizosphere of scabby potatoes $(17,32)$. In an assessment of limited numbers of naturally infested soil samples from fields where common scab was found, approximately $10^{3}$ to $10^{5} \mathrm{CFU}$ of pathogenic Streptomyces per gram of soil was found in most of the samples, with one exception in which approximately $10^{6} \mathrm{CFU}$ of pathogenic Streptomyces per gram of soil was present. These results are in good agreement with the findings of Conn et al. (6) and Wang and Lazarovits (32) on bulk soils using plating methods. The high standard deviations in $\mathrm{Ct}$ values observed in triplicate aliquots of some soil samples suggest that Streptomyces is not evenly distributed in soil. Since only $1 \mathrm{~g}$ soil was used for DNA extraction, it is important to ensure that adequate soil sampling strategies are used, and that DNA extraction is reproducibly executed.

Often it is difficult to distinguish common scab and powdery scab, especially in the early stages of disease development. Of seven tubers with difficult to distinguish common or powdery scab symptoms, approximately $10^{1}$ to $10^{5} \mathrm{pg}$ of pathogenic Streptomyces DNA was detected in DNA extracts from $1 \mathrm{~g}$ of tuber lesion tissue. Spongospora subterranea was also detected in two of these tubers (X. S. Qu, and B. J. Christ, unpublished data), indicating the scab lesion was a mixture of common scab and powdery scab. From our experience in identifying potato diseases, it is not unusual to find common scab and powdery scab coexisting on single tubers. This PCR assay may be useful for the identification of pathogenic Streptomyces on scabby tubers with atypical symptoms that are difficult to diagnose visually.

A very important aspect of common scab management in potato production is the use of pathogen-free seed potatoes. Approximately $10^{1}$ to $10^{3} \mathrm{pg}$ of DNA of pathogenic Streptomyces was detected in total DNA extracts from $1 \mathrm{~g}$ of tuber tissue on three out of six asymptomatic tubers. These results are in agreement with the findings of others that asymptomatic seed tubers may harbor a measurable population of pathogenic Streptomyces that are potential sources of inoculum of pathogenic Streptomyces into potato fields $(32,37)$. The PCR assay developed in this study may serve as a sensitive and fast method to assess seed tubers.

Many factors influence common scab disease incidence, including virulence of the pathogenic bacterial strain, potato cultivar resistance, soil type, and environmental conditions, but some results suggest a relationship between the amount of pathogenic Streptomyces in soil and the incidence of common scab on tubers. Wang and Lazarovits (32) and Keinath and Loria (18) observed a correlation between potato common scab incidence and inoculum density of pathogenic Streptomyces in the rhizosphere, and Wanner (33) found a correlation between initial inoculum density and radish common scab. Accurate quantification of pathogenic Streptomyces in larger numbers of soil samples with subsequent determination of disease incidence under varying conditions must be accomplished to validate these results. Potentially a threshold value could be determined to indicate soils that would be at high risk for common scab disease. The method presented here makes such a study feasible.

To better understand the epidemiology of potato common scab, and to devise better measures to control the disease, it is important to use accurate methods to measure the quantity of pathogenic strains on tubers and in soils. The main advantages of our real-time PCR assay are high sensitivity, specificity, excellent efficiency, and freedom from post-PCR handling steps, which make it an ideal tool to assess target pathogens in large numbers of samples. This assay can be used for accurate detection and quantification of pathogenic Streptomyces in host plant tissues and soils, which is an important step to develop an integrated approach to control common scab disease.

\section{ACKNOWLEDGMENTS}

This research was supported by a grant from the United States Department of Agriculture-Agricultural Research Service Potato Program and by United States Department of Agriculture-Agricultural Research Service CRIS project 1275-21220-187-00D.

\section{LITERATURE CITED}

1. Bentley, S. D., Chater, K. F., Cerdeno-Tarraga, A. M., Challis, G. L., Thomson, N. R., James, K. D., Harris, D. E., Quail, M. A., Kieser, H., Harper, D., Bateman, A., Brown, S., Chandra, G., Chen, C. W., Collins, M., Cronin, A., Fraser, A., Goble, A., Hidalgo, J., Hornsby, T., Howarth, S., Huang, C. H., Kieser, T., Larke, L., Murphy, L., Oliver, K., O’Neil, S., Rabbinowitsch, E., Rajandream, M. A., Rutherford, K., Rutter, S., Seeger, K., Saunders, D., Sharp, S., Squares, R., Squares, S., Taylor, K., Warren, T., Wietzorrek, A., Woodward, J., Barrell, B. G., Parkhill, J., and Hopwood, D. A. 2002. Complete genome sequence of the model actinomycete Streptomyces coelicolor A3(2). Nature 417:141-147.

2. Bouchek-Mechiche, K., Gardan, L., Andrivon, D., and Normand, P. 2006. Streptomyces turgidiscabies and Streptomyces reticuliscabiei: One genomic species, two pathogenic groups. Int. J. Syst. Evol. Micr. 56:2771-2776

3. Bukhalid, R. A., Chung, S. Y., and Loria, R. 1998. nec1, a gene conferring a necrogenic phenotype, is conserved in plant-pathogenic Streptomyces spp, and linked to a transposase pseudogene. Mol. Plant-Microbe Interact. 11:960-967.

4. Bukhalid, R. A., and Loria, R. 1997. Cloning and expression of a gene from Streptomyces scabies encoding a putative pathogenicity factor. J. Bacteriol. 179:7776-7783.

5. Bukhalid, R. A., Takeuchi, T., Labeda, D., and Loria, R. 2002. Horizontal transfer of the plant virulence gene, nec1, and flanking sequences among genetically distinct Streptomyces strains in the Diastatochromogenes cluster. Appl. Environ. Microbiol. 68:738-744.

6. Conn, K. L., Leci, E., Kritzman, G., and Lazarvits, G. 1998. A quantitative method for determining soil populations of Streptomyces and differentiating potential potato scab-inducing strains. Plant Dis. 82:631638.

7. Cullen, D. W., and Lees, A. K. 2007. Detection of the nec1 virulence gene and its correlation with pathogenicity in Streptomyces species on potato tubers and in soil using conventional and real-time PCR. J. Appl. Microbiol. 102:1082-1094.

8. Doering-Saad, Kampfer, C., P., Manulis, S., Kritzman, G., Schneider, J., Zakrzewska-Czerwinska, J., Schrempf, H., and Barash, I. 1992. Diversity among Streptomyces strains causing potato scab. Appl. Environ. Microbiol. 58:3932-3940.

9. Doyle, J. J., and Doyle, J. L. 1990. Isolation of plant DNA from fresh tissue. Focus 12:13-15.

10. Fry, B. A., and Loria, R. 2002. Thaxtomin A: Evidence for a plant cell wall target. Physiol. Mol. Plant Pathol. 60:1-8.

11. Goyer, C., and Beaulieu, C. 1997. Host range of Streptomycete strains causing common scab. Plant Dis. 81:901-904.

12. Healy, F. G., and Lambert, D. H. 1991. Relationships among Streptomyces spp. causing potato scab. Int. J. Syst. Bacteriol. 41:479-482.

13. Healy, F. G., Wach, M., Krasnoff, S. B., Gibson, D. M., and Loria, R. 2000. The txtAB genes of the plant pathogen Streptomyces acidiscabies encode a peptide synthetase required for phytotoxin thaxtomin A production and pathogenicity. Mol. Microbiol. 38:794-804.

14. Hill, J., and Lazarovits, G. 2005. A mail survey of growers to estimate potato common scab prevalence and economic loss in Canada. Can. J. Plant Pathol. 27:46-52.

15. Janssen, P. H. 2006. Identifying the dominant soil bacterial taxa in libraries of $16 \mathrm{~S}$ rRNA and $16 \mathrm{~S}$ rRNA genes. Appl. Environ. Microbiol. 72:1719-1728

16. Joshi, M., Rong, X., Moll, S., Kers, J., Franco, C., and Loria, R. 2007. Streptomyces turgidiscabies secretes a novel virulence protein, necl, which facilitates infection. Mol. Plant-Microbe Interact. 20:599-608.

17. Keinath, A. P., and Loria, R. 1989. Population dynamics of Streptomyces scabies and other actinomycetes as related to common scab of potato. Phytopathology 79:681-687.

18. Keinath, A. P., and Loria, R. 1991. Effects of inoculum density and cultivar resistance on common scab of potato and population-dynamics of Streptomyces scabies. Am. J. Potato 68:515-524.

19. Kers, J. A., Cameron, K. D., Joshi, M. V., Bukhalid, R. A., Morello, J. E., Wach, M. J., Gibson, D. M., and Loria, R. 2005. A large, mobile 
pathogenicity island confers plant pathogenicity on Streptomyces species. Mol. Microbiol. 55:1025-1033.

20. Kreuze, J. F., Suomalainen, S., Paulin, L., and Valkonen, J. P. T. 1999. Phylogenetic analysis of 16S rRNA genes and PCR analysis of the nec1 gene from Streptomyces spp. causing common scab, pitted scab, and netted scab in Finland. Phytopathology 89:462-469.

21. Kritzman, G., and Grinstein, A. 1991. Formalin application against soilborne Streptomyces. Phytoparasitica 19:248-249.

22. Lambert, D. H., and Loria, R. 1989. Streptomyces scabies sp. nov., nom. rev. Int. J. Syst. Bacteriol. 39:387-392.

23. Lawrence, C. H., Clark, M. C., and King, R. R. 1990. Induction of common scab symptoms in aseptically cultured potato tubers by the vivotoxin, thaxtomin. Phytopathology 80:606-608.

24. Lehtonen, M. J., Rantala, H., Kreuze, J. F., Bang, H., Kuisma, L., Koski, P., Virtanen, E., Vihlman, K., and Valkonen, J. P. T. 2004. Occurrence and survival of potato scab pathogens (Streptomyces species) on tuber lesions: Quick diagnosis based on a PCR-based assay. Plant Pathol. 53:280-287.

25. Leiner, R. H., Fry, B. A., Carling, D. E., and Loria, R. 1996. Probable involvement of thaxtomin A in pathogenicity of Streptomyces scabies on seedlings. Phytopathology 86:709-713.

26. Loria, R., Bukhalid, R. A., Fry, B. A., and King, R. R. 1997. Plant pathogenicity in the genus Streptomyces. Plant Dis. 81:836-846.

27. Loria, R., Kers, J., and Joshi, M. 2006. Evolution of plant pathogenicity in Streptomyces. Annu. Rev. Phytopathol. 44:469-487.

28. Ndowora, T. C. R., Kinkel, L. L., Jones, R. K., and Anderson, N. A. 1996. Fatty acid analysis of pathogenic and suppressive strains of Streptomyces species isolated in Minnesota. Phytopathology 86:138-143.
29. Schaad, N. W., Jones, J. B., and Chun, W. 2001. Laboratory Guide for the Identification of Plant Pathogenic Bacteria. American Phytopathological Society, St. Paul, MN

30. Takeuchi, T., Sawada, H., Tanaka, F., and Matsuda, I. 1996. Phylogenetic analysis of Streptomyces spp. causing potato scab based on 16S rRNA sequences. Int. J. Syst. Bacteriol. 46:476-479.

31. Wang, A., and Lazarovits, G. 2004. Enumeration of plant pathogenic Streptomyces on postharvest potato tubers under storage conditions. Can. J. Plant Pathol. 26:563-572.

32. Wang, A., and Lazarovits, G. 2005. Role of seed tubers in the spread of plant pathogenic Streptomyces and initiating potato common scab disease. Am. J. Potato Res. 82:221-230.

33. Wanner, L. A. 2004. Field isolates of Streptomyces differ in pathogenicity and virulence on radish. Plant Dis. 88:785-796.

34. Wanner, L. A. 2006. A survey of genetic variation in Streptomyces isolates causing potato common scab in the United States. Phytopathology 96:1363-1371.

35. Wanner, L. A. 2007. A new strain of Streptomyces causing common scab in potato. Plant Dis. 91:352-359.

36. Weller, S. A., Elphinstone, J. G., Smith, N. C., Boonham, N., and Stead, D. E. 2000. Detection of Ralstonia solanacearum strains with a quantitative, multiplex, real-time, fluorogenic PCR (TaqMan) assay. Appl. Environ. Microbiol. 66:2853-2858.

37. Wilson, C. R., Ransom, L. M., and Pemberton, B. M. 1999. The relative importance of seed-borne inoculum to common scab disease of potato and the efficacy of seed tuber and soil treatments for disease control. J. Phytopathol. 147:13-18. 